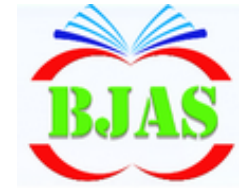

ISSN $1814-5868$
Available online at http://bjas.bajas.edu.iq https://doi.org/10.37077/25200860.2020.33.2.07 College of Agriculture, University of Basrah

\section{Basrah Journal of Agricultural Sciences}

E-ISSN: 2520-0860

\title{
Morphological Responses in Two Palm Species Against the Elevation of Ultra Violet Radiation Under Ambient Conditions
}

\author{
Sajeda Y. Swaid ${ }^{1}$, Abdulminam H. Ali ${ }^{2} \&$ Eman M. Abdul Zahra ${ }^{2}$ \\ ${ }^{1}$ Date Palm Research Centre, University of Basrah, Basrah, Iraq \\ ${ }^{2}$ Biology Department, Science College, Basrah University, Iraq \\ Corresponding author e-mail: abdulminamhussienali@gmail.com*
}

Received 5 May 2020; Accepted 12 August 2020; Available online 17 October 2020

\begin{abstract}
Present study was investigate the effect of different UV-doses on morphological defending system features of two palm species Phoenix dactylifera L. and Washingtonia filifera (Lindl.) H. Wendl. The results showed that the morphological and biomass traits of both palm species grown for 30 days under UV-B with a rate of 2 hrs.day $^{-1}$ were almost improved. Where, the highest leaf width was recorded $(1.1$ and $0.7 \mathrm{~cm})$ respectively. Conversely, UV-treatment (4-10 hrs.day ${ }^{-1}$ ) has adversely affected on almost morphological and biomass features of both species. Where, the less leaf widths were recorded 0.95, 0.8, $0.73,0.45,0.43$ and $0.40 \mathrm{~cm}$ in both palm species. Besides, results also spotted changes in leaf's surface appearances. However, present investigation concluded that morphological features and biomass of both species were unaffected with low dose of UV-radiation (2 hrs.day $\left.{ }^{-1}\right)$. But, date palm ( $P$. dactylifera L.) was capable to survive at high dose of radiation

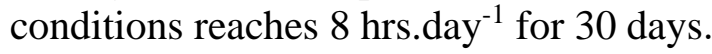

Key words: Arecaceae, Phoenix dactylifera, Washingtonia filifera, Morphological responses, UV-B.

\section{Introduction}

Since plant uses the sunlight for photosynthesis, it exposed to a different spectrum of (UV) radiation. In general, UV Light divide into three types according to wavelength, these are UV-A (320-400 nm), UV -B (280-320 nm) and UV-C (100-280nm). Fortunately, the UV-C and some $\mathrm{UV}-\mathrm{B}$ radiations are absorbed by the ozone layer located in the stratosphere. But, due to the thinning of the ozone layer, some harmful UV-B rays penetrate the atmosphere and hence it affects the ecosystem in our planet. (Caldwell et al.,1989; Hidema \& Kumagai, 2006; Kravets et al., 2012; Rai \& Agrawal, 2017).However, many studies revealed that the exposure of plants to harmful UV radiation induced diverse photomorphogenic responses including: reduction of leaf surface area, curling (folding up) of leaves, yellowing, and growth inhibition. (Stapleton, 1992; Sharma et al. 1998; Hollosy, 2002; Frohnmeyer \& Staiger, 2003; Ulm \& Nagy, 2005; Jenkins, 2009).

For example, Singh et al. (2008), reported that the symptoms of leaves exposing to UV-stress are: initially the colour change to bronzy, then leaf folding up and finally glazing. Nevertheless, These symptoms developed when plant stay for 
a long period under UV-radiation, where irregular patches on leaf surface start exposed, and ending with brown necrotic spots.

In date palm, Niazwali (2016) studied the impact of high dose UV-B radiation on morphological and biomass parameters and found a notable reduction in shoot height, leaf area, fresh and dry weight. Current study aimed to assess the morphological protection system in two palm species against different doses of UV radiation. Find out strengthens and weakness points in morphological defending system of both species. Therefore, this study also helps us to refinements our understanding about the safe use of the UV-light in plant breeding.

\section{Materials \& Methods}

The experiment was conducted in the Department of Biology, University of Basrah, Iraq during the season 2017-2018. Two species of Arecaceae family date palm Phoenix dactylifera L. cv. 'Barhii' and California fan palm Washingtonia filifera (Lindl.) $\mathrm{H}$. Wendl were chosen for this study. Where palms are most economically important plant families. Many foods products derived from palms. Moreover, palms are also used in landscaping. Seeds of date palm cv.'Barhii' were collected on summer season from orchard located in Uosffan, Abu Al-Khaseeb South eastern of Basrah Province. While, California fan palm ( $W$. filifera) were collected from the tree cultivated in the Garden of Science College, University of Basrah. Selected viable seeds were washed in tap water for 15 minutes, and then sterilized with $20 \%$ sodium hypochlorite for 20 minutes, followed by washing three times with sterilized distilled water. Sterilized seeds then soaked in distilled water under room temperature for 72 hrs. Following, one seed was sown individually in plastic pots sized $(12 \times 10.8 \times 8.8 \mathrm{~cm})$, having a mixture of clay, peat moss and vermiculite $(1: 1: 1 \mathrm{v}: \mathrm{v})$. Plants then stored at growth room at $30 \circ \mathrm{C}$ and $50-60 \%$ relative humidity. Seedlings irrigated manually every 2-3 days or when the plant needs. Plants watered one time per week with half strength of Hoagland's fertilizer.

\section{Culture conditions (Design of UV-B System)}

One UV-B tube light with emission range (30w, $\lambda 280-320 \mathrm{~nm}$ ) was used as source of harmful electromagnetic ionizing radiation. The UV-tube was fixed between normal white florescent lights. Supplementary white florescent lights or photosynthetic active radiation (PAR) with a rate of $75 \mu \mathrm{mol} . \mathrm{M}^{-2} \mathrm{~s}^{-1}$ was provided by using 5 fluorescent tubes. A $16.8^{-1} \mathrm{hrs}$. (light/dark) photoperiod was followed in the current study. The PAR and UV-B light supplementary tubes were fixed on the top of the wooden chamber. Distance between light source and plants were $80 \mathrm{~cm}$. To avoid plant phototropism, walls of a wooden cabinet covered with reflective paper.

The similar healthy germinated seedling of both palm species divided in 5 groups of 10 pots each. UV-B exposure dose was given to 5 groups with different rates as follows: 0, 2, 4, 8

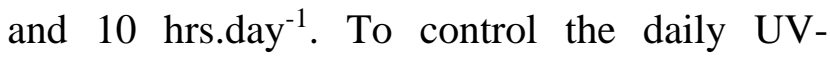
exposure time for each group a programmable digital timer type (TS-EE8) had been used. To study the development parameters, plant samples were taken after 30 days of grown under UV-B stress.

\section{Plants growth variables}

Shoots and roots length: Shoot height was calculated by the measuring the shoot from the soil level to the tip and indicated in $\mathrm{cm}$, whereas root length was measured from the tip 
of the root to the first cotyledonary node and expressed in $\mathrm{cm}$.

Leaves width: width of a leaf was estimated by measuring of the widest region of leaf nearly at half (middle) of the leaf. The centimetres unit expressed the value. Fresh and Dry Weight: Fresh weights of whole plant (shoot and root) measured after seedlings harvest and washed in tap water. After recording the fresh weight, the plant materials were dried by using the oven at 70c for $24 \mathrm{hrs}$. The fresh and dry weights were determined by utilizing the electronic balance (Sartorius analytical balance model ENTRIS224-1S). Weight values expressed in Grams.

\section{Scanning electron Microscope (SEM) Study}

Leaf samples of different treatments were fixed in fixative solution for 4 hours at room temperature or stored in the refrigerator if it will not be processed the following day. Fixative solution was discarded and samples were rinsed twice in $0.1 \mathrm{M}$ buffer solution for $15 \mathrm{~min}$ each. For specimen desiccation - critical point drying, samples were transferred into the prechilled critical point dryer chamber after quickly blotting off most alcohol. Samples were transferred to a clean desiccator then samples were mounted onto stubs with double sided tape. Metal coating of the specimen were applied in evaporator or sputter.de Almeida et al.(2012). Plant specimens viewed with a scanning electron microscope (SEM) (FESEM Nova 450 Nanosem, Netherlands).

\section{Statistical Analysis}

The experiment was randomly designed with two factors. Results were analysed using the height of the 8 and $10 \mathrm{hrs}$. treated W. filifera seedlings were adversely affected by the UV- analysis of variance (ANOVA). The means were separated, by using the least significant difference (LSD) at $5 \%$. ata represent the means of three replicates for each treatment.

\section{Results}

\section{Shoot length changes}

Plants are sessile organism needs to adjust their growth properties in order response the environmental changing. Light is one of variable environmental factor, which is necessary for photosynthesis. Plants are enabling to modulate their morphology and metabolism according to seasonal or daytime changes of light. (Kami et al, 2010; Vanhaelewyn et al., 2016). However, since the end of twentieth centenary, researchers gave a scientific attention on the effect of UV$\mathrm{B}$ on living organisms, and they found that this type of irradiation has a direct impact on plants (Jansen, 2002; Frohnmeyer \& Staiger, 2003; Ulm \& Nagy, 2005; Jenkins, 2009). But, UV-B stress occur only when plants subjected to high doses of this irradiation (Jenkins, 2009; Jansen \& Bornman, 2012).

Present study revealed that the height of the seedlings of $P$. dactylifera $\mathrm{L}$. increased when subjected to UV- stress for 2 and 4 hrs. where the plant height reached 24 and $22 \mathrm{~cm}$ respectively. Interestingly, the height of date palm seedlings was reduced significantly at high doses of UV- B radiation treatments (8-10 hrs.day $^{-1}$ )(see Table 1).In W. filifera the height of the seedling increased at UV- stress for 2 hrs., where the seedling height reached $22.35 \mathrm{~cm}$ (Table 1 and Plate 1A). Then, seedlings height slightly reduced to $18.33 \mathrm{~cm}$ after $4 \mathrm{hrs}$. of UVB stress. Furthermore, the

B, where it recorded 18.2 and 17 $\mathrm{cm}$ respectively (Table1). 


\section{Swaid et al./ Basrah J. Agric. Sci., 33 (2): 80-94, 2020}

Present study revealed that the height of the seedlings of $P$. dactylifera $\mathrm{L}$. increased when subjected to UV- stress for 2 and 4 hrs. where the plant height reached 24 and $22 \mathrm{~cm}$ respectively. Interestingly, the height of date palm seedlings was reduced significantly at high doses of UV- B radiation treatments (8-10 hrs.day $^{-1}$ )(see Table 1).In W. filifera the height of the seedling increased at UV- stress for $2 \mathrm{hrs.}$ where the seedling height reached $22.35 \mathrm{~cm}$ (Table 1) and (Plate 1A). Then, seedlings height slightly reduced to $18.33 \mathrm{~cm}$ after $4 \mathrm{hrs}$. of UVB stress. Furthermore, the height of the 8 and 10 hrs. treated $W$. filifera seedlings were adversely affected by the UV-B, where it recorded 18.2 and $17 \mathrm{~cm}$ respectively (Table 1$)$.

Table (1): Effects of UV radiation on shoot height of $P$. dactylifera and $W$. filifera seedlings grown for 30 days under lab. conditions.

\begin{tabular}{|c|c|c|c|c|c|c|}
\hline Species & \multicolumn{5}{|c|}{ Exposure Time (hrs. day $\left.{ }^{-1}\right)$ to UV-Radiation } & \multirow[t]{2}{*}{ Effect of species } \\
\hline & 0 & 2 & 4 & 8 & 10 & \\
\hline \multicolumn{7}{|c|}{ Shoot height $(\mathrm{cm})$} \\
\hline P. dactylifer & $21.00 \pm 1.73^{\mathrm{bc}}$ & $24.00 \pm 0.58^{\mathrm{a}}$ & $22.00 \pm 0.57^{\mathrm{ab}}$ & $18.80 \pm 0.44^{\text {cde }}$ & $16.00 \pm 1.16^{\mathrm{e}}$ & $20.36 \pm 0.98^{\mathrm{A}}$ \\
\hline W. filifera & $20.33 \pm 0.88^{\text {bcd }}$ & $22.35 \pm 1.45^{\mathrm{ab}}$ & $18.33 \pm 0.88^{\mathrm{cc}}$ & $18.20 \pm 0.58^{\mathrm{de}}$ & $17.00 \pm 0.58^{\mathrm{e}}$ & $19.24 \pm 0.98 \mathrm{~A}$ \\
\hline Effect of Time & $20.67 \pm 0.69^{\mathrm{B}}$ & $23.18 \pm 0.69^{\mathrm{A}}$ & $20.17 \pm 0.69^{\mathrm{BC}}$ & $18.50 \pm 0.69^{\mathrm{C}}$ & $16.50 \pm 0.69^{\mathrm{D}}$ & \\
\hline \multicolumn{2}{|c|}{ Species: N.S } & \multicolumn{3}{|c|}{ Time: 1.94} & \multicolumn{2}{|c|}{ Species and Time: 2.75} \\
\hline
\end{tabular}

Super scripted Different small letters suffixed on the right side represented a significant difference at 5\% level. Super scripted Different capital letters on the right side of third row (Effect of time) represented significant difference of effect of time at 5\% level. The effect of UV-stress on two palm species (column on the right side of the table): Super scripted capital letters suffixed on the right side represented significant difference for species at $5 \%$ level. The mean values of three replications \pm SE(Standard Error). 
Leaf width changes and others modifications

Results indicated that the leaves of the date palm and California fan palm seedlings subjected to UV-B for twohrs.day ${ }^{-1}$, showed a significant increasing inwidths $(1.1$ and $0.7 \mathrm{~cm})$ respectively (Table 2 and Plate 1B). Conversely, UVtreatment (4-10 hrs.day $\left.^{-1}\right)$ have adversely affected on the leaf width on both palm species under study. Where, leaf widths of both species were recorded $0.95,0.8,0.73,0.45,0.43$ and $0.40 \mathrm{~cm}$ (Table 2, Plate-1B; Plate-2 B, D and E and Plate-3A-D).Besides, results spotted changes in leaf's surface appearances (Table 3). First, leaf's surface appearance changed from smoothness to roughness, when UV dose rose

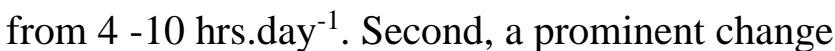
was recorded specifically in the date palm leaf blade. It is leaf folding (leaf involution) and twisting mechanism (Plate $2 \mathrm{~A}-\mathrm{F}$ ). These types of operation give the leaf more flexibility to avoid the excess exposing to harmful radiation, as well as keep the plant survived until the ended of UV-stress threat. Thus, these mechanisms, let the leaf regulates the daily light (PAR +UV) interception, and resist the high doses of UV stress. Besides, results spotted changes in leaf's surface appearances (Table 3).

Table (2): Effects UV radiation on leaf width of $P$. dactylifera and $W$. filifera seedlings grown for 30 days under lab. conditions.

\begin{tabular}{|c|c|c|c|c|c|c|}
\hline \multirow[t]{2}{*}{ Species } & \multicolumn{2}{|r|}{$\mathrm{S}$} & \multicolumn{3}{|c|}{ Exposure Time $\left(\mathrm{hrs}^{- \text {day }^{-1}}{ }^{-1}\right.$ to UV-Radiatic } & \multirow[t]{2}{*}{ Effect of Species } \\
\hline & 0 & 2 & 4 & 8 & 10 & \\
\hline & \multicolumn{5}{|c|}{ Leaf Width (cm) } & \\
\hline P. dactylifer & $1.00 \pm 0.00^{\mathrm{a}}$ & $1.10 \pm 0.00^{\mathrm{ab}}$ & $0.95 \pm 0.33^{b}$ & $0.80 \pm 0.33^{c}$ & $0.73 \pm 0.06^{\mathrm{c}}$ & $0.92 \pm 0.04^{\mathrm{A}}$ \\
\hline W. filifera & $0.50 \pm 0.00^{\mathrm{d}}$ & $0.70 \pm 0.06^{\mathrm{c}}$ & $0.45 \pm 0.03^{\mathrm{d}}$ & $0.43 \pm 0.07^{\mathrm{d}}$ & $0.40 \pm 0.06^{\mathrm{d}}$ & $0.50 \pm 0.04^{B}$ \\
\hline Effect of Time & $0.75 \pm 0.03^{\text {В }}$ & $0.90 \pm 0.03^{\mathrm{A}}$ & $0.70 \pm 0.03^{\mathrm{BC}}$ & $0.62 \pm 0.03^{\mathrm{C}}$ & $0.57 \pm 0.03^{\mathrm{D}}$ & \\
\hline
\end{tabular}

Species: $\quad 0.05$

Time: 0.09

Species and Time: $\mathbf{0 . 1 2}$

Super scripted Different small letters suffixed on the right side represented a significant difference at 5\% level. Super scripted Different capital letters on the right side of third row (Effect of time) represented significant difference of effect of time at $5 \%$ level. The effect of UV-stress on two palm species (column on the right side of the table): Super scripted capital letters suffixed on the right side represented significant difference for species at $5 \%$ level. The mean values of three replications \pm SE (Standard Error). 
Swaid et al./ Basrah J. Agric. Sci., 33 (2): 80-94, 2020
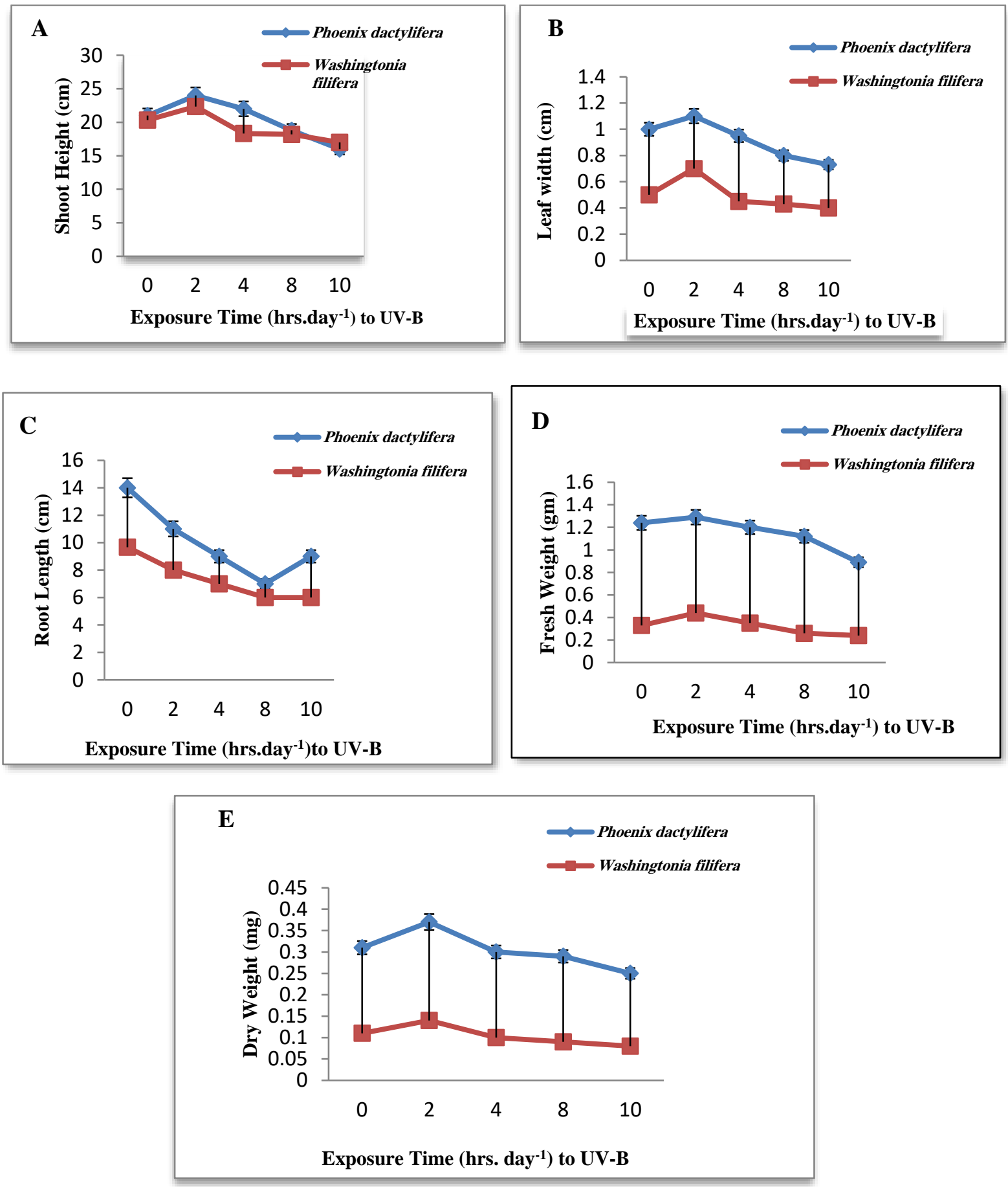

Plate (1): Effect of 30 days of UV-B radiation on growth parameters of both palm species $(P$. dactylifera) and (W. filifera): A-Shoot height growth, B -Leaf width, C-Root length, D- Fresh Weight and E- Dry Weight. 
Swaid et al./ Basrah J. Agric. Sci., 33 (2): 80-94, 2020

Table (3): Effects UV radiation on morphological parameters of leaf of both palm species grown for 30 days in ambient conditions.

\begin{tabular}{|c|c|c|c|c|c|c|}
\hline \multirow{2}{*}{ Species } & \multirow{2}{*}{ Leaf Traits } & \multicolumn{5}{|c|}{ Exposure Time (hrs.day ${ }^{-1}$ ) to UV-Radiation } \\
\hline & & 0 & 2 & 4 & 8 & 10 \\
\hline \multirow{3}{*}{ P. dactylifera } & Surface Type & Smooth & smooth & smooth & rough & Rough \\
\hline & $\begin{array}{c}\text { Discolouration (Photo } \\
\text { bleaching) }\end{array}$ & - & - & - & - & + \\
\hline & Curling & - & - & - & + & ++ \\
\hline \multirow{3}{*}{ W. filifera } & Surface Type & Smooth & smooth & smooth & rough & Rough \\
\hline & $\begin{array}{c}\text { Discolouration (Photo } \\
\text { bleaching) }\end{array}$ & - & - & + & ++ & ++ \\
\hline & Curling & - & - & + & + & ++ \\
\hline
\end{tabular}

In contrast, the (W. filifera) interact differently with the high doses of UV -B. where a thick waxy layer as well as a nonoriented appendages accumulated on the leaf surface (Fig-3F). Interestingly, the photo bleaching appeared at the started on seedlings leaf grown under moderate dose of UV (4 hrs.day $\left.{ }^{-1}\right)$, and next chlorosis increased dramatically with the UV-B elevation (Table 3 and Plate $3 \mathrm{G}$ and $\mathrm{H}$ ). In date palm, it seems that it has different strategies to face against the elevations of UV-B. However, leaf discolouration or (chlorosis) was noted in seedlings irradiated for $10 \mathrm{hrs}^{-d a y}{ }^{-1}$ (Plate2GandH).

Interestingly, the scanning electron microscope revealed a deformation on the stomata apparatus of leaves subjected to high doses of UV-B in both palm species as a result of deposited a thick waxy cuticle on surface (Plate 2I and J; Plate 4A-D). Furthermore, in date palm the waxy material emerged prominently as scales on the surface (Plate 2I and J). In (W. filifera), it was noted that a cluster of non-oriented silica had gathered on leaf surface as well as thick epicuticular wax (Plate $3 \mathrm{E}, \mathrm{F}$ and Plate $4 \mathrm{C}$ E). But no such materializes were spotted on the leaf surface of date palm.

\section{Root length}

Results showed that the root length in both species of palms was decreased dramatically and according to the time of radiation exposing (14-9cm) and $(9-6 \mathrm{~cm})$. Details were summarized in (Table 4 and Plate-1C).

\section{Fresh and dry weight}

The fresh and dry weight of both palm species were not affected with low dose of UV-stress ( 2 hrs.day $\left.{ }^{-1}\right)$, rather increased significantly.

In date palm the plants' fresh and dry weight were not much influenced with high doses of UV- light (4-8 hrs.day ${ }^{-1}$ ) (1.12gm) (Table 5 and 6, Plate-1D and E). But, in the desert palm(W. filifera), fresh and dry weights of plants were influenced effectively when plant subjected to 4-10 hrs. ${ }^{\text {day-1 }}$ of UV-radiation (0.35-0.24gm) (Table-5 and 6, Plate-1D and E). 
Swaid et al./ Basrah J. Agric. Sci., 33 (2): 80-94, 2020

Table (4): Effects UV radiation on root length of $P$. dactylifera and $W$. filifera seedlings grown for 30 days under lab. conditions.

\begin{tabular}{|c|c|c|c|c|c|c|}
\hline \multirow[t]{3}{*}{ Species } & \multicolumn{5}{|c|}{ Exposure Time $\left(\right.$ hrs.day $\left.^{-1}\right)$ to UV-Radiation } & \multirow[t]{3}{*}{ Effect of Species } \\
\hline & 0 & 2 & 4 & 8 & 10 & \\
\hline & \multicolumn{5}{|c|}{ Root Length (cm) } & \\
\hline P. dactylifer & $14.00 \pm 0.58^{\mathrm{a}}$ & $11.00 \pm 0.58^{\mathrm{b}}$ & $9.00 \pm 1.16^{\mathrm{bd}}$ & $7.00 \pm 1.16^{\text {de }}$ & $9.00 \pm 0.58^{\mathrm{bd}}$ & $10.00 \pm 0.72^{\mathrm{A}}$ \\
\hline W. filifera & $9.67 \pm 0.33^{b c}$ & $8.00 \pm 0.58^{\text {cde }}$ & $7.00 \pm 0.58^{\mathrm{de}}$ & $6.00 \pm 0.58^{\mathrm{e}}$ & $6.000 .58 \pm^{e}$ & $7.33 \pm 0.72^{\mathrm{B}}$ \\
\hline Effect of Time & $11.50 \pm 0.51^{\mathrm{A}}$ & $9.50 \pm 0.51^{\mathrm{B}}$ & $8.50 \pm 0.51^{\mathrm{BC}}$ & $6.30 \pm 0.51^{\mathrm{C}}$ & $7.50 \pm 0.51^{\mathrm{C}}$ & \\
\hline
\end{tabular}

Super scripted Different small letters suffixed on the right side represented a significant difference at $5 \%$ level. Super scripted Different capital letters on the right side of third row (Effect of time) represented significant difference of effect of time at 5\% level. The effect of UV-stress on two palm species (column on the right side of the table): Super scripted capital Letters suffixed on the right side represented significant difference for species at $5 \%$ level. The mean values of three replications \pm SE (Standard Error).

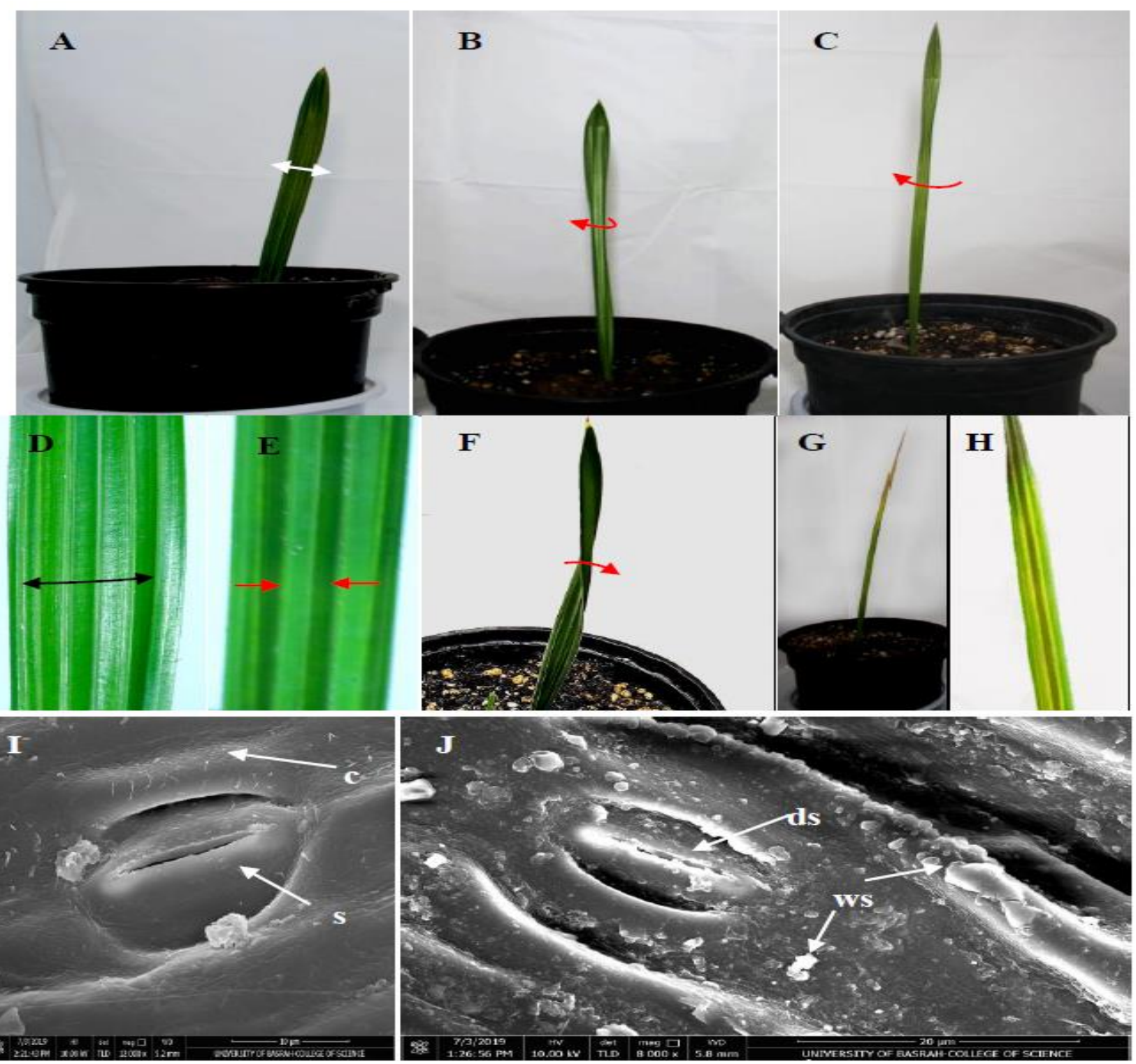


plate (2) (A): Date palm seedling grown on PAR light only. normal leaf with fully expanded surface (note the white arrows). (B-C) seedling subjected to PAR+UV-B 8hrs./day. Note the reduction on leaf's surface area by rolling mechanism (observe the red arrows). (D) Digitally magnified photograph (40 times) for leaf at the normal condition. (E) Digitally magnified photograph (40 times) showing curling of leaf exposed to high dose of UV. (F)Twisting mechanism (note the red arrow) in seedling leaf subjected to high dose of UV stress (8-hrs. day $\left.^{-1}\right)$. ( $G$ and $H$ ) leaf discolouration or (chlorosis) on date palm seedlings irradiated to UV-B for 10 hrs.(I) Scanning electron microscopy of leaf of (P. dactylifera) after 30 days of growth under normal condition. Note the normal cuticle (c) and stomata (s), (Scalebar $=10 \mu \mathrm{m})$. (J) Scanning electron microscopy to leaf grown under UV stress. Observe the abnormal deposited waxy scales (ws) on the cuticle layer and deformed stomata (ds), (Scale bar $=10 \mu \mathrm{m})$.

Table (6) Effects UV radiation on dry weight of $P$. dactylifera and $W$. filifera seedlings grown for 30 days under lab. conditions. Super scripted Different small letters suffixed on the rightside represented a significant difference at $5 \%$ level.

\begin{tabular}{|c|c|c|c|c|c|c|}
\hline \multirow{2}{*}{ Species } & \multicolumn{5}{|c|}{ Exposure Time (hrs. day ${ }^{-1}$ ) to UV-Radiation } & \multirow{2}{*}{ Effect of Species } \\
\hline & 0 & 2 & 4 & 8 & 10 & \\
\hline & \multicolumn{5}{|c|}{ Dry Weight (gm) } & \\
\hline P. dactylifer & $0.31 \pm 0.05^{\mathrm{b}}$ & $0.37 \pm 0.01^{\mathrm{a}}$ & $0.30 \pm 0.02^{\mathrm{b}}$ & $0.29 \pm 0.01^{\mathrm{b}}$ & $0.25 \pm 0.01^{\mathrm{c}}$ & $0.30 \pm 0.02^{\mathrm{A}}$ \\
\hline W. filifera & $0.11 \pm 0.02^{\mathrm{de}}$ & $0.14 \pm 0.01^{\mathrm{d}}$ & $0.10 \pm 0.00^{\mathrm{e}}$ & $0.09 \pm 0.01^{\mathrm{e}}$ & $0.08 \pm 0.01^{\mathrm{e}}$ & $0.10 \pm 0.02^{B}$ \\
\hline Effect of time & $0.21 \pm 0.01^{\mathrm{b}}$ & $0.25 \pm 0.01^{\mathrm{a}}$ & $0.20 \pm 0.01^{\mathrm{b}}$ & $0.19 \pm 0.01^{\mathrm{b}}$ & $0.17 \pm 0.01^{\mathrm{c}}$ & \\
\hline \multicolumn{3}{|c|}{ Species: 0.02} & \multicolumn{2}{|c|}{ Time:0.04 } & \multicolumn{2}{|c|}{ Species and Time: 0.05} \\
\hline
\end{tabular}

Super scripted Different capital letters on the right side of third row (Effect of time) represented significant difference of effect of time at $5 \%$ level. The effect of UV-stress on two palm species (column on the right side of the table): Super scripted capital Letters suffixed on the right side represented significant difference for species at $5 \%$ level. The mean values of three replications \pm SE(Standard Error). 


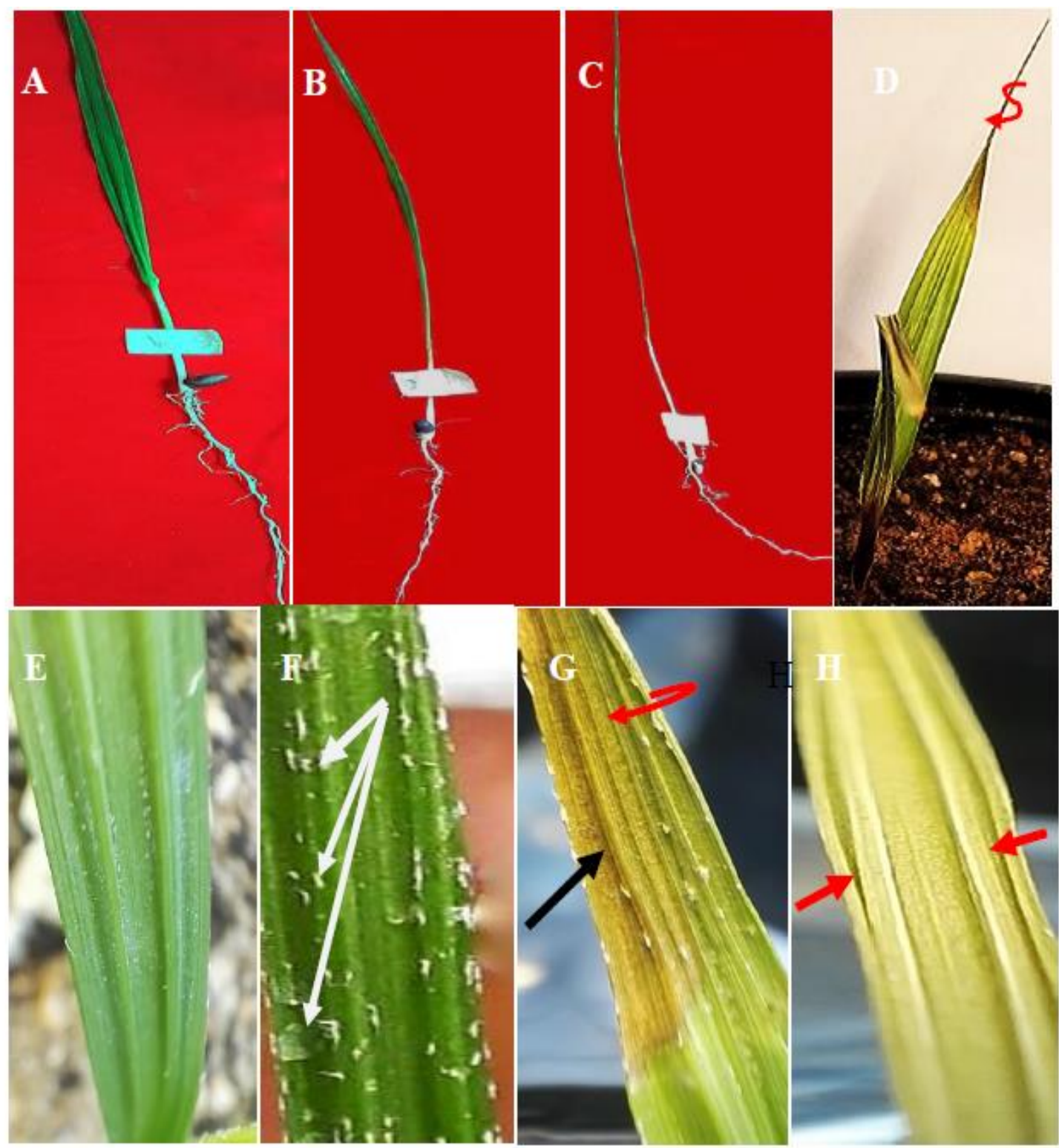

Plate (3): (A) California fan palm seedling grown on PAR light only. Note the fully expanding leaf

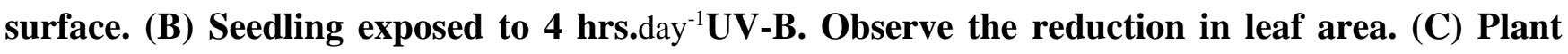
grown under high UV-stress $\left(8 \mathrm{hrs} . \mathrm{day}^{-1}\right)$. See the leaf's surface was reduced as a result of rolling mechanism. (D) Seedling subjected to (10 hrs./day) of UV-light. Note the irreversible curling leaf (red twisted arrow). (E) Digitally magnifying photograph (40 times) for leaf of control plant, Note the fully expanded leaf with very smooth surface. (F) Digitally magnifying photograph (40 times) for leaf of plant grown under $4 \mathrm{hrs}$./day UV-stress for 30 days. Note the rough leaf surface and non-oriented appendages (white arrows). ( $G$ and $H$ ) Note the photo bleaching (black arrow), and leaf folded or irreversible curling (red arrows) on plant leaf exposed to UV-B for 8-10hrs.day 
Swaid et al./ Basrah J. Agric. Sci., 33 (2): 80-94, 2020

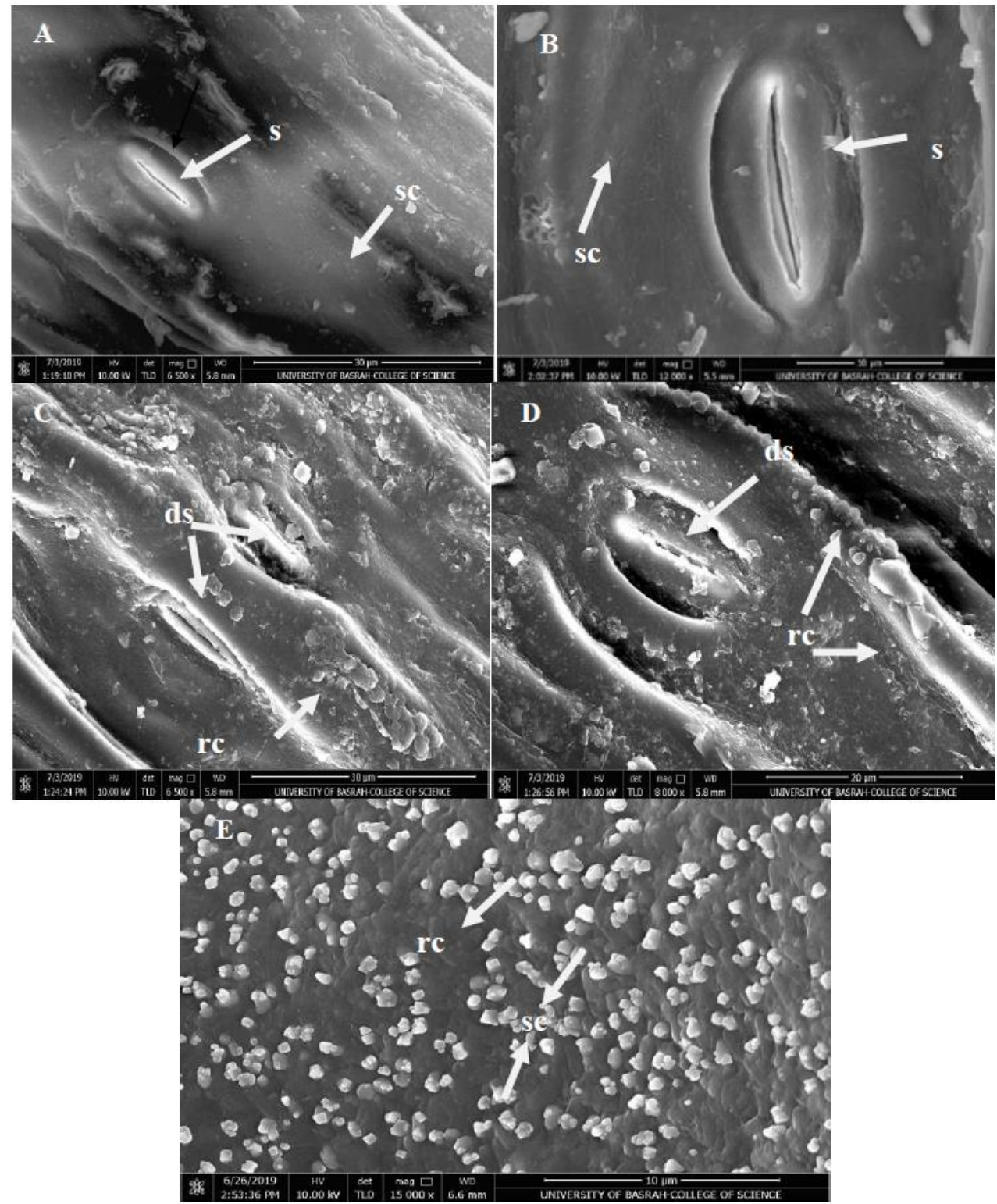

Plate(4): Scanning electron microscopy for normal and UV-stressed leaf of (W. filifera) after 30 days of growth and development under Lab. conditions. (A) Note the normal smooth cuticle layer ( $\mathrm{sc}$ ) and regular stomata (s), Scale bar $=30 \mu \mathrm{m}$. (B) Magnifying part of normal smooth cuticle (sc) showed no silica crystals, Scale bar=10 $\mu \mathrm{m}$. (C) Scanning electron microscopy for UV-stressed leaf, note the deformed stomata, thick rough cuticle (rc) and nonoriented silica crystals deposited on the cuticle layer, Scale bar=30 $\mu \mathrm{m}$. (D) Magnifying part of same part, Scale bar $=20 \mu \mathrm{m}$.(E) Magnifying part of leaf surface exhibited a thick cuticle wax cover or rough cuticle (rc) and non-oriented silica crystals (sc), Scale bar $=10 \mu \mathrm{m}$.

\section{Discussion}

Data extracted from the present study indicated that both palm species have a morphological defence system that able to faces the UV-stress, but not equal. Therefore, under low dose of UV-B ( 2 hrs. $^{-1 \text { day }}$ ), both species showed a significant increasing in some morphological traits. These findings are in line with Kumari \& Agrawal (2010), who obtained the same results in lemongrass (Cymbopogon 
citrates) where, the morphological features of plants were unaffected with low doses of UVB. Klem et al. (2019) reported that in barley (Hordeum vulgare), the growth and photosynthetic performance were enhanced, when plant exposed to a combination of lights consist of red, blue, far-red, and UV-A. Jansen \& Bornman (2012) suggested that the low dose of UV-B induced photomorphogentic acclimation in plant without any signs of acclimation.

Also, current findings are in harmony with a results obtained by Niazwali (2016) who reported that date palm seedlings was able to resisted and tolerate the UV-B stress up to 8 hrs.day $^{-1}$. Where, most desert plant able to develop special strategies to attenuate different environmental stress including the ionizing radiations. In contrast, California fan palm showed deterioration in most of growth parameters. and ultimately plants died.

Regarding the leaf folding up process in plants. This adaptive procedure mostly applied by xerophytic plants to minimizing abiotic stress like (overheating, dehydration and light interception) (Alvarez et al., 2008). Scientist have different explanations of this interesting defence mechanism in plants. Nevertheless, Alvarez et al. (2008) described the effect of the hygroscopic pressure changes on bulliform cells (motor cells) associated to avoid light interception by reducing the leaf surface area in Tristachya leiostachya. Accordingly, most of the leaf epidermal cells increase their wall thickness during the exposing to UV-stress, and thus it disrupted the stomatal structure. As a result, these cells loses their expansion through the temporary plasmolysis (reducing the hygroscopic turgor pressure of the cell). Thus, motor cells become more flaccid and the leaf enabled to involutes or folding up. Current study supports this allegation, where it was found that the UV-B deposited more epiculticuler wax on leaf surface. This resulted in deformation of stomata structure. Finally, this action deficit the water flow from soil to the leaf. Lastly, these mechanisms may cause a dropped in biomass barometers of both species. On the contrary, Alvarez et al. (2008)that the motor cells in some species were not play an active role during the leaf curling process, due to accumulation to large amounts of silicon on their outermost walls. The same effect was recognized in (W. filifera) leaf, where leaf folded up irreversibly when plant exposed to high dose of UV-B (8-10 hrs.day $\left.{ }^{-1}\right)$.

Kakani et al. (2003) suggested other path for leaf curling process. Where, they believed that the conversion of Indole-acetic-acid to 3methylene oxindole, let the curling action or cupping to take place. This suggestion was supported recently by molecular study. Where, Tanaka et al. (2014) found, that the over expression of UGT74Dlgene increases the oxindole-3-acetic acid production that induced the leaf curling. Plants shoot height and root length, is another morphological factors have monitored in the current study. Data indicated that the shoot height, and root length were much affected by high dose treatment of UV in the two palm species. Same results obtained by Liu et al. (2013), Rajendiran et al. (2015) and Niazwali (2016).

However, with respect to the important factor, that governs the response of plants to UV-B stress. Scientist found a relationship between UVR8 (signaling protein) and triggers of various morphological and physiological changes in plants to stand up against such stress. (Mao et al., 2015). In palms, this needs much intensive investigations on the molecular level. 


\section{Conclusions}

Present study concluded that morphological features and biomass of both species were unaffected with low dose of UV-radiation (2 hrs.day $\left.{ }^{-1}\right)$ or at least it can withstand for a long period. But, date palm ( $P$. dactylifera L.) capable to survived at high dose of radiation conditions reaches 8 hrs.day-1for 30 days. However, UV-B resistance between palm species or date palm cultivars is a crucial factor and needs more investigations. But, the results of the present work open the possibility future work for selecting the palm species that able to survive under UV-B radiation. Moreover, current study invites all research workers to focusing their studies towards the UV-B photoreceptor. Where, this receptor triggers morphological and physiological changes to attenuate the UV radiation.

\section{Acknowledgment}

The authors would like to express deep gratitude to the Head of Biology Department, Prof. Dr. Munaff J. Abd Al-Abass for his unlimited support during the accomplish this study. Our grateful thanks are also extended to Prof. Dr. Abdulla A. Alansari and Assistant Prof. Dr. Abbas K. Obbaid, Department of Horticulture and Garden Engineering, Collage of Agriculture, Basrah University for his helping in doing statistical analysis. Our depth acknowledges to Prof. Dr. Abdulkreem M. Abed, Department of Horticulture and Garden Engineering, College of Agriculture, Basrah University for his valuable consultation. Finally, we would like to express our special thanks of gratitude to Assistant Prof. Dr. Jalal J. Hassan, Electron Microscope Unit, Department of Physics, College of Science for his assistance in prepared and photographed the samples.

\section{Conflict of interest}

The authors declare that they have no conflict of interest photographed the samples.

\section{References}

Alvarez, J.M., Rocha, J.F., \& Machado, S. R. (2008). Bulliform cells in Loudetiopsis chrysothrix (Nees) Conertand Tristachya leiostachya Nees (Poaceae): structure in relation to function. Brazilian Archives of Biology and Technology, 51, 113-119. https://www.scielo.br/pdf/babt/v51n1/a14v51n1.

Caldwell, M. M., Teramura, A. H., \& Tevini, M. (1989). The changing solar ultraviolet, climate and the ecological consequences for higher plant. Trends in Ecolology and Evolution, 4, 363366.https://doi.org/10.1016/0169-5347(89)901006PlumX Metrics

de Almeida, S. L., Schmidt, É. C., Rodrigues, A. C., \& Bouzon, Z. L. (2012). Effects of Natural Radiation, PAR and Artificial ultraviolet radiation-B on the Ultrastructure and Histochemistry of Leaf of Oryza sativa L. American Journal Plant Sciences, 3, 13611368.https ://www .scirp. org/html/3-2600 47124043. htm http://dx .doi. org/10.4236/ ajps.2012.310164

Frohnmeyer, H., \& Staiger, D. (2003). Ultraviolet-B radiation-mediated responses in plants: balancing damage and protection. Plant Physiology, 133, 1420-14. https: //doi.org/10.1104/pp.103.030049.

Gonzalez, R., Mepsted, R., Wellburn, A. R., \& Paul, N. D. (1998). "Non-photosynthetic mechanisms of growth reduction in pea (Pisum sativum) exposed to UV-B radiation. Plant Cell Environment, 21, 23-32. https://onlinelibrary.wiley.com/doi/pdf/10.1046/j.13 65-3040.1998.00243.x

Hidema, J., \& Kumagai, T. (2006). Sensitivity of rice to ultraviolet-B radiation. Annals of Botany, 97, 933942. https://doi.org/10.1093/aob/mcl044

Hollósy, F. (2002). Effects of ultraviolet radiation on plant cells. Micron, 33, 179-197. http://www.esalq.usp.br/lepse/imgs/conteudo_thumb /Effects-of-ultraviolet-radiation-on-plant-cells.pdf

Jenkins, G. I. (2009). Signal transduction in responses to UV-B radiation. Annual Review Plant Biology, 60, 407-431.

https://doi.org/10.1146/annurev.arplant.59.032607.0 92953 


\section{Swaid et al./ Basrah J. Agric. Sci., 33 (2): 80-94, 2020}

Jansen, M. A. K. (2002). Ultraviolet-B radiation effects on plants: induction of morphogenic responses. Physiologia Plantarum, 116, 423-429. https://doi.org/10.1034/j.1399-3054.2002.1160319.x

Jansen, M., \& Bornman, J. F. (2012). UV-B radiation: from generic stressor to specific regulator. Physiologia Plantarum. 145, 501-504. https://doi.org/10.1111/j.1399-3054.2012.01656.x

Klem, K., Gargallo-Garriga, A., Rattanapichai, W., Oravec, M., Holub, P., Vesela, B., Sardans, J., Peñuelas, J., \& Urban, O. (2019). Distinct morphological, physiological, and biochemical responses to light quality in barley leaves and roots. Frontiers in Plant Science, 10, 1-19. https://doi.org/10.3389/fpls.2019.01026

Kakani, V. G., Reddy, K. R., Zhao, D., \& Sailaja, K. (2003). Field crop responses to ultraviolet-B radiation: A review. Agricultural and Forest meteorology, 120, 191-218. https://doi.org/10.1016/j.agrformet.2003.08.015

Kravets, E. A., Zelena, L. B., Zabara, E. P., \& Blume, Y. B. (2012). Adaptation strategy of barley plantsto UV-B radiation. Emirates Journal of Food and Agriculture, 2012. 24, 632-645 https://doi.org/ $10.9755 /$ ejfa. v24i6.14682

Kumari, R., \& Agrawal, S. B. (2010). Supplemental UV-B induced changes in leaf morphology, physiology and secondary metabolites of an Indian aromatic plant Cymbopogon citrates (D. C.) Staph under natural field conditions. International Journal Environmental Science, 67, 655675.https://doi.org/10.1080/00207233.2010.513828

Liu, B.. Liu, X., Li, Y., \& Herbert, S. J. (2013). Effects of enhanced UV-B radiation on seed growth characteristics and yield components in soybean. Field Crops Research, 154, 158-163. https://doi.org/10.1016/j.fcr.2013.08.006

Mao, K., Wang, L., Li, Y-Y., \& Wu, R. (2015). Molecular cloning and functional analysis of UV resistance locus8(PeUVR8) from Populus euphratica. PLoS One, 10, 1-18. https://doi.org/10.1371/journal.pone.0132390.

Niazwali, S. A. (2016). Examining the growth and performance of the effect of UV-B radiation on United Arab Emirates Date Palm tree (Phoenix dactylifera). M. Sc. Thesis, UAE University, 69pp.https:// scholarworks.uaeu.ac.ae /cgi/ viewcontent.cgi? article $=1330 \&$ context $=$ all_theses
Nogue's, S., Allen, D. J.; Morison, J. I. L., \& Baker, N. R. (1998). Ultraviolet-B Radiation effects on water relations, leaf development and photosynthesis in Droughted Pea Plants. Plant Physiolology, 117, 173181. https://doi.org/10.1104/pp.117 .1.173

Rai, K., \& Agrawal, S. B. (2017). Effect of UVradiation on morphological and physiological and biochemical aspects of plants: An overview. Journal Science Research, 61, 87-113. https://www.bhu.ac.in/research_pub/jsr61/_pdf_files /06.\%20Ksharma\%20Rai\%20\&\%20SB\%20Agrawal .pdf

Rajendiran, K., Vidya, S., Gowsalya, L., \& Thiruvarasan, K. (2015). Impact of supplementary UV-B radiation on the morphology, growth and yield of Vignamungo(1.) Hepper var. ADT-3. International Journal of Food, Agriculture and Veterinary Sciences, 5, 104-112. https://www.cibtech.org/J-FOOD-AGRI-

VETERINARYSCIENCES/PUBLICATIONS/2015/Vol_5_No_2/1 7-JFAV-019-RAJENDIRAN-IMPACT.pdf

Sharma, P. K., Amand, P., Sankhalkar, S., \& Shetye, R. (1998). Photochemical and biochemical changes in wheat seedlings exposed to supplementary ultraviolet-B radiation. Plant Science, 21, 132-145 . https://doi.org/10.1016/S0168-9452(97)00266-5

Singh, S. K., Surabhi, G. K., Gao, W., \& Reddy, K. R. (2008). Assessing genotypic variability of cowpea (Vigna unguiculata (L.) Walp.) to current and projected ultraviolet-B radiation. Journal of Photochemistry and Photobiology Biology, 93, 7181.https://doi.org/10.1016/j.jphotobiol.2008.07.002

Stapleton, A. E. (1992). Ultraviolet Radiation and plants: Burning questions. American Society of Plant Physiologists, $\quad 89, \quad$ 1353-1358. https://doi.org/10.1105/tpc.4.11.1353

Tanaka, K., Hayashi, K., Natsume, M., Kamiya, Y., Sakakibara, H., Kawaide, H., \& Kasahara, H. (2014). UGT74D1 catalyzes the glucosylation of 2oxindole-3-acetic acid in the auxin metabolic pathway in Arabidopsis. Plant Cell Physiology, 55, 218-228. https://doi.org/10.1093/pcp/pct173

Ulm, R., \& Nagy, F. (2005). Signaling and gene regulation in response to ultraviolet light. Current Opinion in Plant Biology, 8, 477-482. https://doi.org/10.1016/j.pbi.2005.07.004 
Swaid et al./ Basrah J. Agric. Sci., 33 (2): 80-94, 2020

Vanhaelewyn, L., Prinsen, E., Straeten, D. V. D., \& Vandenbussche, F. (2016). Hormone-controlled UVB responses in plants. Journal of Experimental
Botany, 67, 4469-4482. https://doi.org/ $10.1093 /$ jxb/erw261

\section{الاستجابة المظهرية لنوعين من النخيل ضد الارتفاع في الأشعة فوق البنفجية تحت الظروف المختبرية \\ ساجده ياسين سويد1 و عبد المنعم حسين علي2 وايمان محمد عبد الزهرة2 \\ 1مركز ابحاث نخيل التمر، جامعة البصرة، البصرة، العراق \\ 2 قسم علوم الحياة، كلية العلوم، جامعة البصرة، العر اق}

المستخلص: بحثت الدراسة الحالية في نأثير جر عات الأشعة فوق البنفجية المختلفة على خصائص النظام الدفاعي المظهري

Washingtonia filifera (Lindl.) H. و نخيل الو اشنطونيا Phoenix dactylifera L. لنو عين من النخيل هما نخيل التمر

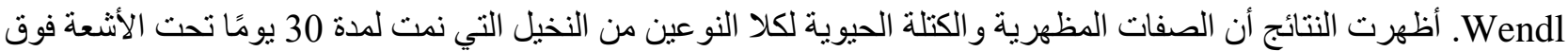

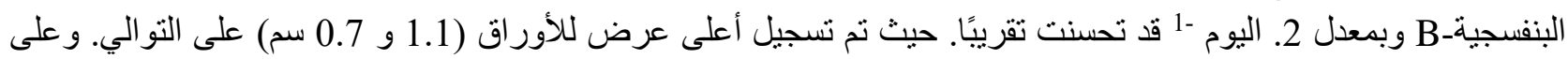
العكس من ذلك ، فإن المعاملة بالأشعة فوق البنفسجية لمدة 4-10 ساعات. اليوم -1 قد أثر سلبًا على الخصائص المظهرية والكتلة

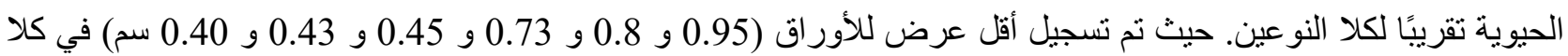

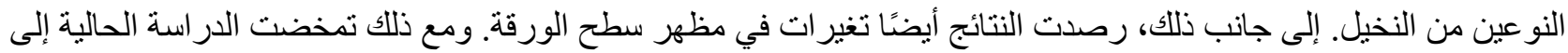

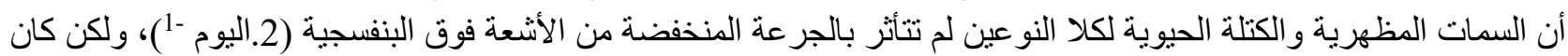
نخيل التمر قادرًا على البقاء بالجرعات العالية من الإشعاع تصل إلى 8 ساعة. اليوم -1 لمدة 30 يوماً. الكلمات المفتاحية: العائلة النخيلية، نخيل التمر، نخيل الو اشنظونيا، الاستجابات المظهرية، الحساسية للاشعة فوق البنفسجية. 